\title{
Role of vitamin A in health and illness
}

\author{
Paweł Marzęda ${ }^{1, B, D, F} \oplus$, Jarogniew J. Łuszczki ${ }^{1,2, A, D-F} \oplus$ \\ ${ }^{1}$ Department of Pathophysiology, Medical University, Lublin, Poland \\ ${ }^{2}$ Isobolographic Analysis Laboratory, Institute of Rural Health, Lublin, Poland \\ A - Research concept and design, B - Collection and/or assembly of data, C - Data analysis and interpretation, \\ $D$ - Writing the article, E - Critical revision of the article, F - Final approval of article \\ Marzęda P, Łuszczki J.J. Role of vitamin A in health and illness. J Pre Clin Clin Res. 2019; 13(3): 137-142. doi: 10.26444/jpccr/112376
}

\begin{abstract}
Introduction. Vitamin A is an essential substance for human well-being and survival. It plays a crucial role in many physiological processes, including growth and differentiation of target tissues, reproduction, proper functioning of the retina and modulation of the immune system. Vitamin A deficiency leads to increased risk of severe infections, numerous diseases and pathological conditions, including disorders of vision, bones, epithelial tissue and immunity. It remains one of the main causes of preventable blindness in children. Nonetheless, excessive intake of vitamin A can also cause serious health problems.

Objective. The aim of this study is to describe and summarize current knowledge about the role of vitamin $A$ in the human organism, as well as to provide general information on its supplementation.

State of Knowledge. Vitamin A is a group of similar organic compounds that cannot be synthesized in the human body, and therefore has to be included in the diet. Vitamin A influences the human body since foetal life. Both deficiency and an excess of vitamin A may cause serious complications. The main sources of the vitamin are meat, fish, poultry and dairy products. Its precursors, such as carotenoids, are present in fruit and vegetables. It is stored mainly in the liver and adipose tissue. Vitamin A has antioxidative attributes.

Conclusion. An adequate intake of vitamin A is crucial for maintaining health and well-being, and deficiency as well as overdose of this vitamin may cause serious complications and diseases.
\end{abstract}

\section{Key words}

vitamin A, retinol, fat soluble vitamin, vitamin A deficiency

\section{INTRODUCTION}

Vitamin A is a name of the group of chemical substances - retinoids (i.e., retinol, retinal, retinoic acid), fat-soluble compounds that are essential for human body. They cannot be produced and have to be provided as a part of the diet. In the animal origin food, vitamin $\mathrm{A}$ is present in ester form - mostly as retinyl palmitate, which is converted in the human body to alcohol - retinol. In plant-based diet, it is present in form of $\beta$-carotene, $\beta$-cryptoxanthin and other pro-vitamin A carotenoids [1]. These substances are less efficient in vitamin A generation process. It is accepted that $6 \mathrm{mg}$ of $\beta$-carotene is required to produce $1 \mathrm{mg}$ of retinal during enzymatic cleavage. However several years ago it has been stated that this conversion is even less efficient and it requires not 6 but, 12 molecules of $\beta$-carotene to produce 1 molecule of vitamin A [2]. Then again this process may be either more or less productive for different sources and types of pro-vitamin A carotenoids [3-5]. Serum concentrations of vitamin A have to stay in equilibrium, for it takes part the cellular differentiation and growth, and at high serum level it exert its toxic effects. Moreover, vitamin A plays a crucial role in vision, immune system function, maintenance of epithelial tissues and reproduction. Nevertheless, lack of vitamin A persists to be one of the most prevalent micronutrient deficiencies and a significant contributor to the global burden of disease, especially in the resourceconstrained countries [6].

Addres for correspondence: Jarogniew J. Łuszczki, Isobolographic Analysis Laboratory, Institute of Rural Health, Lublin, Poland

E-mail: jarogniew.luszczki@umlub.pl

Received: 22.08.2019; accepted: 16.09.2019; first published: 20.09.2019
Absorption, transport and storage. Efficiency of absorption, processing and storage of preformed vitamin A varies from $70 \%-90 \%$. For carotenoids, the bioavailability range is wider and oscillates between $35 \%-88 \%$ [7, 8]. Crucial for improving the absorption of vitamin $\mathrm{A}$ in vulnerable populations is the knowledge that the presence of dietary fat enhances absorption of both pro-vitamin A carotenoids and preformed vitamin A [9-11].

Up to $80 \%$ of vitamin A in the body is stored in the liver, mainly in the stellate cells, and mostly as retinyl esters [12]. A part of retinol esters from chylomicra is uptaken by spleen, lung and adrenal gland to maintain concentration [13]. Lesser amounts of retinyl esters can be found in kidney and intestine $[13,14]$. An undervalued role in retinol storing is played by adipose tissue, which can also gather $\beta$-carotenoids $[15,16]$. Vitamin A occurs in cis- and trans-geometric isomeric forms [17], and interconversion between them readily takes place in the body. All-trans retinoic acid is the ligand of nuclear receptors, such as retinoic acid receptors (RARs), and 11-cisretinal is required in the visual cycle [18].

Retinol is transported from the liver to the tissues as a complex with retinol-binding protein (RBP), which is synthesized primarily in hepatocytes. This stability of complex retinol:RBP in plasma is enhanced by its binding to transthyretin [19]. RBP is a negative acute-phase reactant; therefore, serum retinol concentrations are decreased during inflammation and infection.

The functions of vitamin A are mediated mainly by its acid derivatives (excluding visual processes), even though the concentration of acid is much smaller than the retinol. Both the cellular and organismal effects of vitamin A are mediated by RARs and retinoid X receptors (RXRs) via 
interactions between receptor-receptor, receptor-DNA and receptor-regulatory proteins [20]. Lecithin retinol acyltransferase (LRAT) is a quantitatively predominant enzyme for catalyzing retinyl ester formation in most tissues [21]. It enables different tissues in which it is present, mainly liver and eye, to uptake and store retinoids. The exception is the adipose tissue where retinyl ester formation occurs despite lack of this enzyme [22]. CRBPs (cellular retinoid binding proteins) cooperate with LRAT in regulating uptake and the metabolism of retinoids. They may be responsible for retinoids toxicity, but they also may serve as targets for novel drugs that would allow for better control of active retinoids levels in specific tissues [22-24]. Furthermore, CRBP-1 (the most diffuse isoform) is involved in wound healing and the remodeling processes of arteries. A common event in cancer pathogenesis is the loss of CRBP-1 expression, which increases malignancy of various cancers [25]. Carotenoids have no specific carrier protein.

In animal products, the major form of vitamin $\mathrm{A}$ is an ester, which is converted to retinol. Sources rich in performed vitamin A are: liver, fish liver oils, dairy products, including: butter, cheese, fat milk, egg yolk and others. Sources rich in pro-vitamin A carotenoids are mostly deep orange and yellow coloured or deep-green leafy plants, i.e.: carrots, sweet potatoes, spinach and mango (Tab. 1).

Table 1. Selected sources of vitamin A [26]

\begin{tabular}{ll}
\hline Food & IU \\
\hline Sweet potatoes & 28,058 \\
\hline Beef liver & 22,175 \\
\hline Spinach & 11,458 \\
\hline Carrots & 9,189 \\
\hline Mangos & 2,240 \\
\hline Apricots & 1,261 \\
\hline Broccoli & 1,208 \\
\hline Ice cream & 1,014 \\
\hline Ricotta cheese & 945 \\
\hline Tomato juice & 821 \\
\hline Cereal fortified with vitamin A & 500 \\
\hline Milk with added vitamin A & 500 \\
\hline Eggs & 260 \\
\hline
\end{tabular}

Fortifying food with vitamin A is socially acceptable and does not require big changes in food habits. The most common and approved types of food for fortification are margarines and oils. They have two big advantages, namely they prevent vitamin A from oxidation during storage and are at low price. Nevertheless, there are many different types of fortified food [3].

Cooking improves the bioavailability of carotenoids. The situation is different for fortified food where processing, storage and preparation may cause big losses of vitamin A. Preformed retinol tends to be a major source of vitamin A in developed countries, while in developing countries most demand is covered by pro-vitamin A carotenoids.

Functions. Nowadays, knowledge about vitamin A properties, metabolism, functions, roles and epigenetic gene regulation is still evolving. The main function of vitamin $\mathrm{A}$ is its role in the vision cycle: 11-cis retinal binds to opsin and forms rhodopsin, which is able to absorb light within the visible spectrum. When 11-cis retinal is hit by a photon, it isomerizes via intermediate species to all-trans retinal, and rapidly releases opsin. This is the initial step of vision. Light-induced hyperpolarization of the rod membrane is amplified by the excited intermediate form of rhodopsin, resulting in the generation of impulses in optic nerves [18]. Retinoic acid is proven to be promoting the proliferation and regulation of the apoptosis of thymocytes. It also takes part in development, proliferation and differentiation of thymic epithelium. Retinoic acid may play a role in negative selection for T cells [27-29].

Vitamin A has regulatory and promoting effects in the immune system. It is valuable enhancer of immunity against numerous infectious diseases and pathologies [30]. Both $\mathrm{T}$ cell-mediated and antibody-dependent immune responses are affected by this vitamin [31], which is relevant in the process of synthesis of immunoglobulins, mostly IgA class $[32,33]$. Retinoids also have repressive activity on IgE; therefore, they may ameliorate allergic diseases mediated by $\operatorname{IgE}[34,35]$.

Another mechanism of action of vitamin A on immune system regulation is the induction of differentiation of naive T cells into T-reg cells through enhancement of Foxp3 gene expression and inhibition of IL-17 expression [29, 36, 37]. A similar, yet more complex phenomenon is observed among naive $B$ cells, which are induced indirectly by vitamin A towards differentiation into B-regs. Moreover, it stimulates secretion of IL-10 [38, 39]. Following all-trans- retinoic acid is a factor that helps to provide both the stability and proper immunoregulatory function of T-regs and B-regs [40]. Via complex mechanisms, vitamin A may serve as a treatment option for chronic inflammatory diseases [41-43].

Vitamin A plays an important role in controlling the population of myeloid cells, providing homeostasis in bone marrow, spleen and peripheral blood [44]. Moreover, in some types of leukemia, all-trans retinoic acid might find its place as part of chemotherapeutic treatment [45].

Vitamin A has a protective effect against tuberculosis. Its deficiency is correlated with the occurrence of tuberculosis in a dose-dependent manner [46]. In bioactive form, alltrans retinoic acid induces antimicrobial responses in $M$. tuberculosis-infected via dendritic cells [47]. Retinoic acid in in vitro conditions inhibits the growth of $M$. tuberculosis. It also reduces its survival rate, making them easier to be lysed when engulfed by macrophages [48].

In post-operative patients with sufficient zinc concentrations, vitamin A contributes to the reduction of oxidative stress [49]. Moreover, zinc increases the absorption of vitamin A, it is also needed for the use of stored vitamin A and works in synergy with it in many functions [8]. Selenium supports beta-carotene-mediated effects. Vitamin A is proven to have, to a certain degree, a therapeutic effect in diseases transmitted through the respiratory system, e.g. measles, infantile diarrhea or pneumonia in children [50,51].

As mentioned above, retinoic acid via nuclear receptors regulates DNA expression. It is involved in differentiation of stem cells, spermatocytes, fibroblasts, osteoblasts and keratinocytes. It is also crucial for the proper differentiation of epithelial tissue. Deficiency of vitamin A leads to generalized metaplasia of epithelial tissues throughout the body, mostly columnar epithelium into keratinized stratified squamous epithelium. It plays a role in xerophthalmia, follicular 
hyperkeratosis, loss of mucous-secreting goblet cells in the trachea and respiratory tract, and carcinogenesis. Vitamin A takes part in controlling enzymes involved in the synthesis of glycosaminoglycans and glycoproteins. Moreover, it takes part in collagen type IV formation. It enhances the response of the organism to micronutrient supplementation. The iron deficiency type of anaemia requires the addition of vitamin A for a full haematologic response. Administering vitamin A improves haemoglobin concentration in response to the supplementation of iron [52-54].

Carotenoids have antioxidant functions. It has been suggested that $\beta$-carotene supplementation in high doses among smokers and workers exposed to asbestos could increase the risk of lung cancer $[55,56]$. Despite unclear data whether or not high levels of $\beta$-carotenids contribute to the development of lung cancer, it is now suggested that a higher intake of dietary $\beta$-carotene rather reduces lung cancer risk [57]. This indicates that $\beta$-carotene from natural sources and synthesized, has a different effect on that risk. Recent meta-analysis confirmed that antioxidant activity of $\beta$-carotene and vitamin A delivered from diet may have a protective effect for risk of lung cancer. This is consistent with previous findings on vitamins $\mathrm{C}$ and $\mathrm{E}$ [58]. It can be assumed that a similar protective effect may be present in the case of many other cancers.

Vitamin A deficiency. Vitamin A deficiency still remains a public health problem, mainly in low- and middle income countries. It is one of the most important causes of preventable blindness in children. It persists in being a significant contributor to morbidity and mortality caused by infections, mainly in children and pregnant women [6]. The main problem in the quantitation of vitamin A deficiency is that the majority of countries have outdated data. Most of the explored nations either have no data on vitamin A deficiency or data that is more than 10 years old [59]. There are still over 80 low- or middle-income countries worldwide that are implementing vitamin A supplementation programmes for children aged from 6 months to 5 year of age. Introducing individual supplementation programmes in each country based on evidence-based decisions seems to be crucial [60]. The main cause of vitamin A deficiency worldwide is an insufficient amount in food. Another vital reason is malabsorption caused by cystic fibrosis, celiac disease, pancreas, liver or bile ducts diseases.

The human body can only store vitamin A in an amount sufficient for one year. The first and main symptom of vitamin A deficiency is night blindness (nyctalopia). Chronic deficiency may cause degenerative changes in the retina, and xerophthalmia which leads to cornea injuries and blindness. Aside from the ocular signs, other symptoms of vitamin A deficiency seem to be quite non-specific. The skin is also affected by lack of vitamin A. It becomes dry, rough and peeling. Some changes in epithelial tissue are observed, mostly atrophic, that cause increased vulnerability to damages and infections, diarrheas and impaired taste. Moreover, it is a factor leading to bone growth impairment, changes in bone structure and shape, fractures, caries and atrophy of dentine. Psoriasis, acne vulgaris and alopecia areata may also appear. Furthermore, anaemia, thyroid dysfunction and impairment of fertility may occur.

Vitamin A deficiency leads to impaired function of tissues, especially in the foetus and newborns. Infants with low vitamin A levels appear to have increased risk of development of bronchopulmonary dysplasia. Changes involve keratinizing metaplasia, necrosis of mucosa, and focal loss of ciliated cells. A new-born has impaired lung function, decreased number of alveoli, defective protection against infections, and are at higher risk for the development of acute diseases in childhood and chronic diseases in adulthood, including lung cancer [61, 62].

Endemic vitamin A deficiency is related to keratinization of the bronchi and tracheae, observed to occur even before alterations in the eye. Another effect of vitamin A deficiency is low FVC (forced vital capacity), a marker of airway obstruction and other extracellular matrix alterations, mostly in kidney, lung and liver $[61,63]$.

Women at reproductive age, especially pregnant women, and young children after weaning are most susceptible to the acquisition of vitamin A deficiency. 190 million preschool children and 19 million pregnant women are affected globally. This equals about $33 \%$ of preschool children and $15 \%$ of pregnant women in populations at risk of vitamin A deficiency. The most affected regions are Africa and Southeast Asia [6]. In 1991, it was estimated that $39 \%$ of children aged 6-59 months in undeveloped countries had vitamin A deficiency. In 2013, that number dropped to $29 \%$. About 95,000 deaths were caused by measles and about 11,000 by diarrhea attributable to the deficiency of vitamin A [64].

In low income Asian countries, children between 6 months and 5-years-old should be given a supplementation of vitamin A to reduce morbidity and mortality of vitamin A deficiency-related diseases, e.g. measles, or severe diarrhea in children. Nevertheless, further studies that compare different delivery mechanisms and doses are needed [65-67]. In contrast, some findings from African countries indicate that supplementation of vitamin A may cause death. Therefore, it should not be recommended in these regions $[68,69]$.

In data from 1998, the WHO noted that vitamin A should not be given in high doses $(>10,000 \mathrm{IU} / \mathrm{d})$ to women who may be pregnant, due to the risk of teratogenic effects in the foetus. Supplementation of 4,000 IU daily as prophylaxis and up to 8,000 IU/day as treatment in the case of deficiency, is considered safe [70]. In guidelines from 2011, the WHO indicates that vitamin A supplementation is recommended only for the prevention of night blindness in areas where severe vitamin A deficiency occurs, only in pregnant women, excluding postpartum women. Single doses of vitamin A $>25,000$ IU are not recommended between days $15-60$ postconception [71]. In women taking > 10,000 IU/d of preformed vitamin A from supplements, it has been calculated that 1 out of 57 babies will be born with a secondary congenital disability. The form of vitamin A identified as the cause of birth defects is the retinol form, not carotenoid. Therefore, precursors intake is not linked to teratogenicity [70]. During pregnancy, there is no established safe minimal dose of oral retinoids.

Vitamin A deficiency can increase the number of bone marrow cells by inhibiting the normal apoptosis process. This disturbance in the signaling pathway may contribute to the development of myeloproliferative disorders [44]. In males, lack of vitamin A causes morphologic changes in all 3 main types of testicular cells: Leydig, Sertoli and germinal cells. This leads to reduced testosterone production and loss of fertility [72]. Vitamin A deficiency is the cause of defects in both cellular and humoral immunity [31]. 
Requirements. It is hard to determine a necessary dose of vitamin A for human body. Due to lack of adequate data, a recommended intake cannot be calculated. The dose of vitamin $\mathrm{A}$ is described as $\mu \mathrm{g}$ of retinol activity equivalents (RAE) to account for the different bioactivities of retinol and provitamin A carotenoids. It is widely accepted that $1 \mu \mathrm{g}$ $\mathrm{RAE}=1 \mu \mathrm{g}$ retinol, $2 \mu \mathrm{g}$ beta-carotene from supplements, $12 \mu \mathrm{g}$ beta-carotene from foods, $24 \mu \mathrm{g}$ alpha-carotene or $24 \mu \mathrm{g}$ beta-cryptoxanthin. In other words, $1 \mathrm{IU}$ of retinol $=0.3 \mu \mathrm{g}$ of RAE; 1 IU of beta-carotene from dietary supplements $=0.15 \mu \mathrm{g}$ RAE; 1 IU of beta-carotene from food $=0.05 \mu \mathrm{g} \mathrm{RAE}$ and 1 IU alpha-carotene or beta-cryptoxanthin $=0.025 \mu \mathrm{g}$ RAE [26].

Currently, the reported recommended daily allowance is 700-900 $\mu \mathrm{g}$ /day $(2,300-4,300 \mathrm{IU})$ for adults and $300-$ $700 \mu \mathrm{g} /$ day $(1,000-2,000 \mathrm{IU})$ for children [73]. Women at reproductive age (13-49 years of age) should receive a dose of 200,000 IU in the case of active corneal lesions on days 1, 2 and 14 ; cases of night blindness or Bitot's spot should be treated with 10,000 IU/day or 25,000 IU/week for over 3 months [74]. In the case of measles, age-dependent doses (50,000-200,000 IU) should be given on days 1 and 2; in xerophthalmia cases on days 1,2 , and 14; and severe malnutrition on day 1 . The mentioned doses seem to be safe; however, in some cases (3-7\%) symptoms of acute hipervitaminosis may appear, like nausea, vomiting, headache and diarrhea [74]. Vitamin A supplements should be taken during a meal of after it, as this facilitates absorption. Women taking contraceptives need less vitamin A [75].

Toxicity. There are 2 main groups that are at particularly risk of vitamin A excess: people who permanently use supplements of vitamin A, and people who consume too big amounts of fortified food or liver. As mentioned above, liver works as a storage of vitamin A, in which it plays a buffering role and esterifies the excess of taken retinoids; therefore, it alleviates the development of intoxication. Two main forms of vitamin A can be distinguished: topical and oral. Each has its own set of adverse effects.

Vitamin A toxic effects occur when it is not bound by transporting proteins like $\mathrm{RBP}$ and is present in a free form. Only in this form it can influence body cells. Adverse effects are not likely to occur when natural food serves as the source of vitamin A. There is no risk of overdosing if one eats numerous plants with high concentrations of carotenoids, but they may gather in fat tissue and change it to a yellowish colour [76]. Adverse effects of high vitamin A levels mostly occur when supplements are used and may appear when the daily dose exceeds $40 \mathrm{mg}$. The most common symptoms are headaches, nausea and ataxia. Raised cerebrospinal fluid pressure may also occur. Other conditions are stomach aches, diarrhea, weight loss, hyperlipidaemia, pachyostosis and bone aches, dry and sensitive skin, hair loss, hypercalcaemia with soft tissues calcification, spleen and liver enlargement.

The most common adverse effect of topical retinoids is epidermal irritation in the form of erythema and peeling. Peeling is the effect of hyperproliferation of the epidermis due to stimulation of retinoic acid receptors [76]. Other side-effects include transient hyperpigmentation and hypopigmentation, allergic contact dermatitis, Koebnerization of psoriasis and ectropion [23]. The majority of these adverse effects will resolve once the doses of vitamin A are reduced or excessive treatment is discontinued.
The adverse effects of oral retinoids can be divided into acute and chronic. Nevertheless, the most severe sideeffect is teratogenicity on neural crest cells and include following abnormalities: craniofacial (cleft lip or palate, microtia or anotia, micrognathia), cardiac (transposition of the great vessels), central nervous system (microcephaly, hydrocephalus) and thymus [77]. Usage of isotretinoin is supposed to raise 25-times the risk of these malformations.

Acute retinoid toxicity mostly appears as mucocutaneous abnormalities; the most common are dry lips, cheilitis, and dryness of mucosa. The possible underlying mechanism is reduction of sebum production, decreased thickness of epidermis, and defective barrier function. Additionally, peeling of the soles and palms or xerosis of the whole skin and mucosa may occur [23].

Chronic toxic effects are present in multiple organs. Effects in central nervous system include headaches, nausea and vomiting. In liver fibrosis and hepatic stellate, cell activatios been observed in patients with hypervitaminosis A [78]. Changes in bones are described as calcinosis, spurs and resorption followed by hypercalcemia [79]. If the condition persist, then besides resorption, it contributes to impaired bone formation, osteoporosis and hip fractures [80]. Muscle weakness and blurred vision may also occur. Common abnormality in laboratory tests is elevation of the triglyceride and cholesterol levels, sometimes together with rise of LDL, and transaminases levels. Elevation of liver enzymes is usually mild and reversible. The treatment may be continued until elevation of cholesterol, liver enzymes or triglycerides persists or worsens.

Before initiation of isotretinoin, the patient should have 2 negative urine or serum $\beta$-HCG pregnancy tests performed 30 days apart, then one once a month and 30 days after the cessation of treatment. When on therapy, assessment of blood triglyceride and cholesterol levels should be performed periodically [81].

\section{CONCLUSIONS}

An adequate intake of vitamin $\mathrm{A}$ is crucial for maintaining health and well-being. Deficiency and overdose of the vitamin can cause serious complications and illnesses. Nevertheless, many uncertainties remain concerning the functioning of vitamin $\mathrm{A}$, and further research is required.

\section{REFERENCES}

1.Shmarakov IO, Yuen JJ, Blaner WS. Carotenoid Metabolism and Enzymology. Carotenoids Hum. Heal., Totowa, NJ: Humana Press; 2013, p. 29-56. https://doi.org/10.1007/978-1-62703-203-2_3.

2. Food and Nutrition Board of the Institute of Medicine Dietary reference intakes. Washington DC: National Academy Press; 2001. p. 170-181

3. WHO/FAO. Guidelines on food fortification with micronutrients. In: Allen L, de Benoist B, Dary O, Hurrell R., editors. Geneva (Switzerland) and Rome (Italy): WHO/FAO; 2006. p. 111-118

4. Burri BJ, Chang JST, Neidlinger TR. $\beta$-Cryptoxanthin- and $\alpha$-carotenerich foods have greater apparent bioavailability than $\beta$-carotene-rich foods in Western diets. Br J Nutr 2011;105:212-9. https://doi.org/10.1017/ S0007114510003260.

5. Tang G, Qin J, Dolnikowski GG, Russell RM, Grusak MA. Spinach or carrots can supply significant amounts of vitamin $\mathrm{A}$ as assessed by feeding with intrinsically deuterated vegetables. Am J Clin Nutr 2005;82:821-8. https://doi.org/10.1093/ajcn/82.4.821. 
6. WHO Global Database on Vitamin A Deficiency. Geneva (Switzerland) WHO; 2009. WHO. Global prevalence of vitamin A deficiency in populations at risk: 1995-2005.

7. Blomhoff R, Blomhoff HK. Overview of retinoid metabolism and function. J Neurobiol 2006; 66: 606-30. https://doi.org/10.1002/neu.20242.

8. Tanumihardjo SA, Russell RM, Stephensen CB, Gannon BM, Craft NE Haskell MJ, et al. Biomarkers of Nutrition for Development (BOND)Vitamin A Review. J Nutr 2016;146:1816S-48S. https://doi.org/10.3945/ jn.115.229708.

9. Ribaya-Mercado JD, Maramag CC, Tengco LW, Dolnikowski GG, Blumberg JB, Solon FS. Carotene-rich plant foods ingested with minima dietary fat enhance the total-body vitamin A pool size in Filipino schoolchildren as assessed by stable-isotope-dilution methodology. Am J Clin Nutr 2007;85:1041-9. https://doi.org/10.1093/ajcn/85.4.1041.

10. Mills JP, Tumuhimbise GA, Jamil KM, Thakkar SK, Failla ML, Tanumihardjo SA. Sweet Potato $\beta$-Carotene Bioefficacy Is Enhanced by Dietary Fat and Not Reduced by Soluble Fiber Intake in Mongolian Gerbils. J Nutr 2009;139:44-50. https://doi.org/10.3945/jn.108.098947.

11. Ribaya-Mercado JD. Influence of Dietary Fat on $\beta$-Carotene Absorption and Bioconversion into Vitamin a. Nutr Rev 2002;60:104-10. https:// doi.org/10.1301/00296640260085831.

12. Grumet L, Taschler U, Lass A. Hepatic Retinyl Ester Hydrolases and the Mobilization of Retinyl Ester Stores. Nutrients 2016;9. https://doi. org/10.3390/nu9010013.

13. Riabroy N, Tanumihardjo SA. Oral Doses of $\alpha$-Retinyl Ester Track Chylomicron Uptake and Distribution of Vitamin A in a Male Piglet Model for Newborn Infants. J Nutr 2014;144:1188-95. https:/doi. org/10.3945/jn.114.191668.

14. Senoo H, Mezaki Y, Morii M, Hebiguchi T, Miura M, Imai K. Uptake and storage of vitamin A as lipid droplets in the cytoplasm of cells in the lamina propria mucosae of the rat intestine. Cell Biol Int 2013;37:n/a n/a. https://doi.org/10.1002/cbin.10140.

15. Wei S, Lai K, Patel S, Piantedosi R, Shen H, Colantuoni V, et al. Retinyl ester hydrolysis and retinol efflux from BFC-1beta adipocytes. J Biol Chem 1997;272:14159-65.

16. Sauvant P, Cansell M, Atgié C. Vitamin A and lipid metabolism relationship between hepatic stellate cells (HSCs) and adipocytes. Physiol Biochem 2011;67:487-96. https://doi.org/10.1007/s13105-0110101-7.

17. Sykes M, Croucher J, Smith RA. Resolution of vitamin A cis/trans isomers resolves proficiency test assessments. Food Chem 2013;141:1597-602. https://doi.org/10.1016/j.foodchem.2013.05.086.

18. Kiser PD, Golczak M, Palczewski K. Chemistry of the Retinoid (Visual) Cycle. Chem Rev 2014;114:194-232. https://doi.org/10.1021/cr400107q

19.Zanotti G, Berni R. Plasma Retinol-Binding Protein: Structure and Interactions with Retinol, Retinoids, and Transthyretin. Vitam. Horm. vol. 69, 2004, p. 271-95. https://doi.org/10.1016/S0083-6729(04)69010-8.

20.Huang P, Chandra V, Rastinejad F. Retinoic acid actions through mammalian nuclear receptors. Chem Rev 2014;114:233-54. https:// doi.org/10.1021/cr400161b.

21. O’Byrne SM, Wongsiriroj N, Libien J, Vogel S, Goldberg IJ, Baehr W, et al. Retinoid Absorption and Storage Is Impaired in Mice Lacking Lecithin:Retinol Acyltransferase (LRAT). J Biol Chem 2005;280:3564757. https://doi.org/10.1074/jbc.M507924200.

22. Moise AR, Noy N, Palczewski K, Blaner WS. Delivery of retinoid-based therapies to target tissues. Biochemistry 2007;46:4449-58. https://doi org/10.1021/bi7003069.

23. Olson JM, Shah NA. Vitamin A Toxicity. StatPearls Publishing; 2018.

24. Bushue N, Wan Y-JY. Retinoid pathway and cancer therapeutics. Adv Drug Deliv Rev 2010;62:1285-98. https://doi.org/10.1016/j. addr.2010.07.003.

25. Doldo E, Costanza G, Agostinelli S, Tarquini C, Ferlosio A, Arcuri G, et al. Vitamin A, cancer treatment and prevention: the new role of cellular retinol binding proteins. Biomed Res Int 2015;2015:624627. https://doi.org/10.1155/2015/624627.

26.Vitamin A - https://ods.od.nih.gov/factsheets/VitaminAHealthProfessional/ (accessed September 12, 2019)

27. Kiss I, Rühl R, Szegezdi É, Fritzsche B, Tóth B, Pongrácz J, et al. Retinoid receptor-activating ligands are produced within the mouse thymus during postnatal development. Eur J Immunol 2008;38:147-55. https:/ doi.org/10.1002/eji.200737342.

28. Wendland K, Niss K, Kotarsky K, Wu NYH, White AJ, Jendholm J, et al. Retinoic Acid Signaling in Thymic Epithelial Cells Regulates Thymopoiesis. J Immunol 2018;201:524-32. https://doi.org/10.4049/ jimmunol.1800418.
29. Bono MR, Tejon G, Flores-Santibañez F, Fernandez D, Rosemblatt M, Sauma D. Retinoic Acid as a Modulator of T Cell Immunity. Nutrients 2016;8. https://doi.org/10.3390/nu8060349.

30. Huang Z, Liu Y, Qi G, Brand D, Zheng S. Role of Vitamin A in the Immune System. J Clin Med 2018;7:258. https://doi.org/10.3390/ jcm7090258.

31. van Bennekum AM, Kong LRWY, Gijbels MJJ, Tielen FJ, Roholl PJM, Brouwer A, et al. Mitogen Response of B Cells, but not T Cells, is Impaired in Adult Vitamin A-Deficient Rats. J Nutr 1991;121:1960-8. https://doi.org/10.1093/jn/121.12.1960.

32. Yang Y, Yuan Y, Tao Y, Wang W. Effects of vitamin A deficiency on mucosal immunity and response to intestinal infection in rats. Nutrition 2011;27:227-32. https://doi.org/10.1016/j.nut.2009.11.024.

33. Pantazi E, Marks E, Stolarczyk E, Lycke N, Noelle RJ, Elgueta R. Cutting Edge: Retinoic Acid Signaling in B Cells Is Essential for Oral Immunization and Microflora Composition. J Immunol 2015;195:136871. https://doi.org/10.4049/jimmunol.1500989.

34. Heine G, Hollstein T, Treptow S, Radbruch A, Worm M. 9-cis retinoic acid modulates the type I allergic immune response. J Allergy Clin Immunol 2018;141:650-658.e5. https://doi.org/10.1016/j.jaci.2017.03.046.

35. Seo G-Y, Lee J-M, Jang Y-S, Kang SG, Yoon S, Ko H-J, et al. Mechanism underlying the suppressor activity of retinoic acid on IL4-induced IgE synthesis and its physiological implication. Cell Immunol 2017;322:4955. https://doi.org/10.1016/j.cellimm.2017.10.001.

36. Ma J, Liu Y, Li Y, Gu J, Liu J, Tang J, et al. Differential role of all -trans retinoic acid in promoting the development of CD4 ${ }^{+}$and CD8 regulatory T cells. J Leukoc Biol 2014;95:275-83. https://doi.org/10.1189/ jlb.0513297.

37. Schambach F, Schupp M, Lazar MA, Reiner SL. Activation of retinoic acid receptor- $\alpha$ favours regulatory $T$ cell induction at the expense of IL17-secreting T helper cell differentiation. Eur J Immunol 2007;37:23969. https://doi.org/10.1002/eji.200737621.

38. Di Caro V, Phillips B, Engman C, Harnaha J, Trucco M, Giannoukakis N. Retinoic acid-producing, ex vivo -generated human tolerogenic dendritic cells induce the proliferation of immunosuppressive B-lymphocytes. Clin Exp Immunol 2013;174:302-17. https://doi.org/10.1111/cei.12177.

39. Iwata Y, Matsushita T, Horikawa M, DiLillo DJ, Yanaba K, Venturi GM et al. Characterization of a rare IL-10-competent B-cell subset in humans that parallels mouse regulatory B10 cells. Blood 2011;117:530-41. https:// doi.org/10.1182/blood-2010-07-294249.

40.Zhou X, Kong N, Wang J, Fan H, Zou H, Horwitz D, et al. Cutting Edge: All-Trans Retinoic Acid Sustains the Stability and Function of Natural Regulatory T Cells in an Inflammatory Milieu. J Immunol 2010;185:2675-9. https://doi.org/10.4049/jimmunol.1000598.

41. Kwok S-K, Park M-K, Cho M-L, Oh H-J, Park E-M, Lee D-G, et al. Retinoic Acid Attenuates Rheumatoid Inflammation in Mice. J Immunol 2012;189:1062-71. https://doi.org/10.4049/jimmunol.1102706.

42. Mauri C, Gray D, Mushtaq N, Londei M. Prevention of arthritis by interleukin 10-producing B cells. J Exp Med 2003;197:489-501.

43. Masnadi Shirazi K, Nikniaz Z, Masnadi Shirazi A, Rohani M. Vitamin A supplementation decreases disease activity index in patients with ulcerative colitis: A randomized controlled clinical trial. Complement Ther Med 2018;41:215-9. https://doi.org/10.1016/j.ctim.2018.09.026.

44. Kuwata T, Wang IM, Tamura T, Ponnamperuma RM, Levine R, Holmes $\mathrm{KL}$, et al. Vitamin A deficiency in mice causes a systemic expansion of myeloid cells. Blood 2000;95:3349-56

45. Lin Y, Lin R, Zhou G, Liu Y, Dong W, Cao Y, et al. Decitabine combined with all-trans retinoic acid as treatment in a case of primary myelofibrosis transforming into acute myeloid leukaemia. J Int Med Res 2019;47:1064-71. https://doi.org/10.1177/0300060518820147.

46. Aibana O, Franke MF, Huang C-C, Galea JT, Calderon R, Zhang Z, et al. Impact of Vitamin A and Carotenoids on the Risk of Tuberculosis Progression. Clin Infect Dis 2017;65:900-9. https:/doi.org/10.1093/ $\mathrm{cid} / \mathrm{cix} 476$.

47. Kim EW, De Leon A, Jiang Z, Radu RA, Martineau AR, Chan ED, et al. Vitamin A Metabolism by Dendritic Cells Triggers an Antimicrobial Response against Mycobacterium tuberculosis. MSphere 2019;4. https:// doi.org/10.1128/mSphere.00327-19.

48. Anand PK, Kaul D, Sharma M. Synergistic action of vitamin D and retinoic acid restricts invasion of macrophages by pathogenic mycobacteria. J Microbiol Immunol Infect 2008;41:17-25.

49. Matos A, Souza G, Moreira V, Luna M, Ramalho A. Vitamin A supplementation according to zinc status on oxidative stress levels in cardiac surgery patients. Nutr Hosp 2018;35:767-73. https://doi. org/10.20960/nh.1666

50. Mayo-Wilson E, Imdad A, Herzer K, Yakoob MY, Bhutta ZA. Vitamin A supplements for preventing mortality, illness, and blindness in 
children aged under 5: systematic review and meta-analysis. BM) 2011;343:d5094-d5094. https://doi.org/10.1136/bmj.d5094.

51. Hu N, Li Q-B, Zou S-Y. [Effect of vitamin A as an adjuvant therapy for pneumonia in children: a Meta analysis]. Zhongguo Dang Dai Er Ke Za Zhi 2018;20:146-53.

52. Muslimatun S, Schmidt MK, Schultink W, West CE, Hautvast JGAJ, Gross R, et al. Weekly Supplementation with Iron and Vitamin A during Pregnancy Increases Hemoglobin Concentration but Decreases Serum Ferritin Concentration in Indonesian Pregnant Women. J Nutr 2001;131:85-90. https://doi.org/10.1093/jn/131.1.85.

53. Ahmed F, Khan MR, Jackson AA. Concomitant supplemental vitamin A enhances the response to weekly supplemental iron and folic acid in anemic teenagers in urban Bangladesh. Am J Clin Nutr 2001;74:108-15. https://doi.org/10.1093/ajcn/74.1.108.

54. Gebremedhin S. Effect of a single high dose vitamin A supplementation on the hemoglobin status of children aged 6-59 months: propensity score matched retrospective cohort study based on the data of Ethiopian Demographic and Health Survey 2011. BMC Pediatr 2014;14:79. https:// doi.org/10.1186/1471-2431-14-79.

55. Alpha-Tocopherol, Beta Carotene Cancer Prevention Study Group. The Effect of Vitamin E and Beta Carotene on the Incidence of Lung Cancer and Other Cancers in Male Smokers. N Engl J Med 1994;330:1029-35. https://doi.org/10.1056/NEJM199404143301501.

56. Omenn GS, Goodman GE, Thornquist MD, Balmes J, Cullen MR, Glass A, et al. Effects of a Combination of Beta Carotene and Vitamin A on Lung Cancer and Cardiovascular Disease. N Engl J Med 1996;334:1150 5. https://doi.org/10.1056/NEJM199605023341802.

57. Yu N, Su X, Wang Z, Dai B, Kang J. Association of Dietary Vitamin A and $\beta$-Carotene Intake with the Risk of Lung Cancer: A Meta-Analysis of 19 Publications. Nutrients 2015;7:9309-24. https://doi.org/10.3390/ nu7115463.

58. Yu N, Su X, Wang Z, Dai B, Kang J. Association of Dietary Vitamin A and $\beta$-Carotene Intake with the Risk of Lung Cancer: A Meta-Analysis of 19 Publications. Nutrients 2015;7:9309-24. https://doi.org/10.3390/ nu7115463.

59. Wirth J, Petry N, Tanumihardjo S, Rogers L, McLean E, Greig A, et al. Vitamin A Supplementation Programs and Country-Level Evidence of Vitamin A Deficiency. Nutrients 2017;9:190. https://doi.org/10.3390/ nu9030190.

60. Wirth J, Petry N, Tanumihardjo S, Rogers L, McLean E, Greig A, et al. Vitamin A Supplementation Programs and Country-Level Evidence of Vitamin A Deficiency. Nutrients 2017;9:190. https://doi.org/10.3390/ nu9030190.

61. Timoneda J, Rodríguez-Fernández L, Zaragozá R, Marín MP, Cabezuelo MT, Torres L, et al. Vitamin A Deficiency and the Lung. Nutrients 2018;10. https://doi.org/10.3390/nu10091132.

62. Biesalski HK, Nohr D. Importance of vitamin-A for lung function and development. Mol Aspects Med 2003;24:431-40.

63. Barber T, Esteban-Pretel G, Marín M, Timoneda J. Vitamin A Deficiency and Alterations in the Extracellular Matrix. Nutrients 2014;6:4984-5017. https://doi.org/10.3390/nu6114984.

64. Stevens GA, Bennett JE, Hennocq Q, Lu Y, De-Regil LM, Rogers L, et al. Trends and mortality effects of vitamin A deficiency in children in 138 low-income and middle-income countries between 1991 and 2013: a pooled analysis of population-based surveys. Lancet Glob Heal 2015;3:e528-36. https://doi.org/10.1016/S2214-109X(15)00039-X.

65. Fisker AB, Bale C, Rodrigues A, Balde I, Fernandes M, Jorgensen MJ, et al. High-dose Vitamin A With Vaccination After 6 Months of Age: A Randomized Trial. Pediatrics 2014;134:e739-48. https://doi.org/10.1542/ peds.2014-0550.
66. Mazumder S, Taneja S, Bhatia K, Yoshida S, Kaur J, Dube B, et al. Efficacy of early neonatal supplementation with vitamin A to reduce mortality in infancy in Haryana, India (Neovita): a randomised, doubleblind, placebo-controlled trial. Lancet 2015;385:1333-42. https://doi. org/10.1016/S0140-6736(14)60891-6.

67. Imdad A, Mayo-Wilson E, Herzer K, Bhutta ZA. Vitamin A supplementation for preventing morbidity and mortality in children from six months to five years of age. Cochrane Database Syst Rev 2017;3:CD008524. https://doi.org/10.1002/14651858.CD008524.pub3.

68. Masanja H, Smith ER, Muhihi A, Briegleb C, Mshamu S, Ruben J, et al. Effect of neonatal vitamin A supplementation on mortality in infants in Tanzania (Neovita): a randomised, double-blind, placebocontrolled trial. Lancet (London, England) 2015;385:1324-32. https:// doi.org/10.1016/S0140-6736(14)61731-1.

69. Edmond KM, Newton S, Shannon C, O’Leary M, Hurt L, Thomas $\mathrm{G}$, et al. Effect of early neonatal vitamin A supplementation on mortality during infancy in Ghana (Neovita): a randomised, doubleblind, placebo-controlled trial. Lancet 2015;385:1315-23. https://doi. org/10.1016/S0140-6736(14)60880-1.

70. Kominiarek MA, Rajan P. Nutrition Recommendations in Pregnancy and Lactation. Med Clin North Am 2016;100:1199-215. https:/doi. org/10.1016/j.mcna.2016.06.004.

71. McGuire S. WHO Guideline: Vitamin A Supplementation in Pregnant Women. Geneva: WHO, 2011; WHO Guideline: Vitamin A Supplementation in Postpartum Women. Geneva: WHO, 2011. Adv Nutr 2012;3:215-6. https://doi.org/10.3945/an.111.001701.

72. Vernet N, Dennefeld C, Rochette-Egly C, Oulad-Abdelghani M, Chambon P, Ghyselinck NB, et al. Retinoic Acid Metabolism and Signaling Pathways in the Adult and Developing Mouse Testis. Endocrinology 2006;147:96-110. https://doi.org/10.1210/en.2005-0953.

73. VitaminARetinoids n.d. https://livertox.nlm.nih.gov/ VitaminARetinoids.htm (accessed July 24, 2019).

74. Ross DA. Recommendations for Vitamin A Supplementation. J Nutr 2002;132:2902S-2906S. https://doi.org/10.1093/jn/132.9.2902S.

75. Haile ZT, Teweldeberhan AK, Chavan B, Francescon J. Hormonal contraceptive use and vitamin A deficiency among women in Tanzania. Int J Gynecol Obstet 2018;141:20-5. https://doi.org/10.1002/ijgo.12396.

76. Kang S, Duell EA, Fisher GJ, Datta SC, Wang ZQ, Reddy AP, et al. Application of retinol to human skin in vivo induces epidermal hyperplasia and cellular retinoid binding proteins characteristic of retinoic acid but without measurable retinoic acid levels or irritation. J Invest Dermatol 1995;105:549-56.

77.Lammer EJ, Chen DT, Hoar RM, Agnish ND, Benke PJ, Braun JT, et al. Retinoic Acid Embryopathy. N Engl J Med 1985;313:837-41. https://doi. org/10.1056/NEJM198510033131401.

78. Nollevaux M-C, Guiot Y, Horsmans Y, Leclercq I, Rahier J, Geubel AP, et al. Hypervitaminosis A-induced liver fibrosis: stellate cell activation and daily dose consumption. Liver Int 2006;26:182-6. https://doi. org/10.1111/j.1478-3231.2005.01207.x.

79. Scheven BA, Hamilton NJ. Retinoic acid and 1,25-dihydroxyvitamin D3 stimulate osteoclast formation by different mechanisms. Bone 1990;11:53-9.

80. Genaro P de S, Martini LA. Vitamin A Supplementation and Risk of Skeletal Fracture. Nutr Rev 2004;62:65-7. https://doi. $\operatorname{org} / 10.1111 /$ j.1753-4887.2004.tb00026.x.

81.Lowell A, Goldsmith LA, Bolognia JL, Callen JP, Chen SC, Feldman SR, Lim HW, et al. American Academy of Dermatology Consensus Conference on the safe and optimal use of isotretinoin: summary and recommendations. J Am Acad Dermatol 2004;50:900-6. https://doi. org/10.1016/j.jaad.2004.02.012. 